In this paper the author described some bones obtained by J. J. Evans, Esq.., in the lower part of the Oxford Clay at Eynsbury, near St. Neot's. They consisted of thirty-seven vertebræ, twenty-one of which are cervical, and apparently complete that series. These presented the characters of the cervical vertebræ of the typical Pliasaurs of the Kimmeridge Clay. The remains of the pelvis included a pubic bone showing a close correspondence in form with those of the Pliosaurs of the Kimmeridge Clay of Ely, and an ischium.

3. "Supplementary Notes on the Fauna of the Cambridge Greensand." By A. J. Jukes-Browne, Esq., B.A., F.G.S.

This paper was supplementary to one communieated to the Society by the author in 1875, in which he maintained that the Upper Greensand does not extend further in a north-westerly direction than West End Hill, near Cheddington, in Buckinghamshire, that the Cambridge Greensand is merely a nodule-bed at the base of the Chalk Marl, resting unconformably upon denuded Gault, to the upper part of which the greater portion of the fauna belongs, and that the remainder of the Fauna. belonging to the deposit itself, consists of species proper to the Chalk Marl rather than to the Upper Greensand. The object of the paper was to indicate certain additions to, and corrections in, the list of fossils upon which these conclusions were supported. The following Gault species were indicated as not previously identified in the Cambridge Greensand:-Nautilus arcuatus, Desh. ; N. inaqualis, Sow.; Turrilites elegans, D'Orb.; ? T. Emericianus, D'Orb.; Ornitkopus histocheila, Gardn.; Brachystoma angularis, Seeley; Turbo Pictetianus, D'Orb.; Pleurotomaria regina, Piet. \& Roux ; ? P. Itieriana, Pict. \& Roux ; Pecten Raulinianus, D'Orb. ; P. subacutus, D'Orb.; and Lima Rauliniana, D'Orb. The author described as new species: Turrilites nobilis, Nautilus, sp. nov., Natica levistriata, Nerita nodulosa, and Lima interlineata, and noted several corrections in the nomenclature adopted in his former list.

\title{
OOREFSPONDENTEF.
}

\section{THE FOSSIL FLORA OF THE TERTIARY BEDS OF BOURNEMOUTH.}

$\mathrm{S}_{\mathrm{R},-\mathrm{As}} \mathrm{Mr}$. Gardner admits that the vegetation of the Bournemouth beds is drifted, the question seems to resolve itself into one of extent. This he thinks he can measure, and pronounces to be very limited. I, on the contrary, venture to doubt that there is anything in the state of this vegetation repugnant to its having travelled various, and in some cases considerable, distances. He insists that the leaves have never been drifted from afar, because of their perfect condition, and because they are often adherent to the twigs; and he adds that " the forms of most temperate aspect are best preserved, so that, to be logically applied, the Drift theory requires the palms, etc., to have been drifted upwards." Now I fail (and I think that your readers will fail also) to perceive any logic in the matter. Short tributaries descending from elevated regions at no great distance would necessarily have a very swift current; and the vegetable spoil of those regions would in consequence be carried far more quickly, and in better condition, towards the place of its deposit than would much of that carried by the main river and by those tributaries which flowed with more sluggish currents through longer tracts of low ground, and brought "the palms, etc."

Mr. Gardner, after intimating that I appear to be totally unacquainted with the aubject, observes that the Fauna of the Thanet sands, Woolwich beds, London Clay, Bracklesham, Headon, Bembridge, and Hempstead beds, ${ }^{1}$ make it plain to us that the climatal conditions

1 The Hempstead beds are not usually regarded as Eocene. 
during the deposit of our Eocene series differed widely at each period. Now my acquaintance with the Eocene formation, and with its Fauna in various ways, ${ }^{1}$ is somewhat more than Mr. Gardner gives me credit for; and I distinetly traverse his suggestion that the Fauna of the beds he names affords (when allowance is made for varying conditions of bottom and depth, and for the difficulty in making comparisons between faunas of which some are marine, some fluviomarine, and some fluviatile, as is the case with these beds) any indication whatever of a diversity of climate. Fortifying the opinion which I have formed from my own acquaintance with these beds, and with their Fauna, by that to the same purport of my father, who has made the study of the Tertiary Mollusca the occupation of the greater part of a long life, I contend that, so far as the past can be judged from what is known of the present, this fauna is of tropical character throughout. It was once thought that the mollusca of the Thanet sands indicated a colder climate than did those of the beds which succeed it, but the subsequent discovery of a Nautilus in these sands has made even that view difficult to be maintained. Moreover, not only do the Eocene beds of Western Europe present this character, but the close similarity between Eocene mollusca found in the Aral-sea region and those from the English and French beds indicates that this climate prevailed under nearly the same latitude as far, at least, as the meridian of $60^{\circ}$ East longitude.

I have trespassed thus much on your space, to vindicate the opposition which I offered to Mr. Gardner's hypothesis of oscillations of climate during the Eocene period; and I could pursue the subject further, as well as offer reasons for disagreeing from his alternative theory of the existence of a mean annual temperature, which permitted the growth of sub-tropical and more temperate forms side by side; but as he expresses his intention of not entering into any discussion with me, this would be undesirable, as I should be sorry to tempt him into any descent from the serene elevation on which he has placed himself.

I would, however, observe that, although the explanation which I offered as to the Hampshire Flora seemed to me the most obvious in that particular case, and although I do look upon both of Mr. Gardner's hypotheses as remote from the truth, I have nothing to say in opposition to Prof. Heer's view that difference of climate according to latitude did not; so far as it is evidenced by fossil vegetation, begin to show itself until late in the Mesozoic division of the Earth's history.

Searles V. Wood, Jun.

THE GONDWANA SERIES OF INDIA. ${ }^{2}$

SIR, - I have some remarks and corrigenda to add to my article on the Gondwana Series of India, ${ }^{3}$

First, as regards the classification of the whole area, as used in the above-mentioned paper, I have to state that it should be, properly, as
follows:

1 Amongst them, the original and first disinterment from the Hampshire cliff, in association with my father (now thirty-four years ago), of the remains of "Alligator, Turtle, and other Reptiles," to which Mr. Gardner in his paper refers. 2 The publication of this letter has been by an unfortunate oversight delayed a
month.-EDrT. Geol. MAG.

3 See Grox. MaG. Dec. II. Vol. III. p. 481. 